\title{
Diversity of Department Chairs in Family Medicine at US Medical Schools
}

Imam M. Xierali, PhD, Marc A. Nivet, EdD, MBA, and William F. Rayburn, MD, MBA

Background: As designated department leader, chairs need to be sensitive to diversity and inclusiveness for recruitment and retention of faculty and visibility to medical students and resident physicians. The purpose of this analysis is to describe diversity by sex and race/ethnicity of family medicine (FM) chairs as a beginning to understand trends.

Methods: This cross-sectional, observational study involved 2018 to 2020 data from the Association of American Medical Colleges Faculty Roster. We compared this data with other department chairs, faculty, medical school matriculants, and the US general population.

Results: There were 407 FM chair observations. While many FM chairs were White males, this was lower than all other clinical departments combined. The proportion of chairs who were under-represented minorities was highest in FM (16.7\%) compared with all other departments. The distributions of FM chairs who were Black, Asian, and Native American were comparable with the US population. The proportions of Hispanic FM chairs, FM faculty, and medical school matriculants lagged behind the population.

Conclusion: Diversity of department chairs in FM is greater than many other clinical departments and more representative of the US general population. Attention by chairs to leadership development of females and recruitment of Hispanic faculty are priorities. (J Am Board Fam Med 2022;35:152-157.)

Keywords: Cross-Sectional Studies, Diversity, Family Medicine, Leadership, Medical Schools, Minority Groups, Physicians, Under-Represented in Medicine

A diverse faculty body is important in medical education settings where care needs, diagnostic accuracy, and treatment efficacy often vary by the sex, race/ethnicity, and cultural status of patients. ${ }^{1-4}$ Faculty who understand these differences may be more effective as teachers and caregivers. Furthermore, diversity among faculty helps ensure a more comprehensive research agenda and drives institutional excellence. ${ }^{5-8}$

Medical school faculty diversity has been linked to the cultural climate on the campus. Diversity of

This article was externally peer reviewed.

Submitted 7 June 2021; revised 20 August 2021; accepted 30 August 2021.

From the Department of Family and Community Medicine, the University of Texas Southwestern Medical Center, Dallas, TX (IMX, MAN); Department of Family Medicine, Medical University of South Carolina, Charleston, SC (WFR).

Funding: None.

Conflict of interest: None.

Corresponding author: Imam M. Xierali, $\mathrm{PhD}$, University of Texas Southwestern Medical Center, Department of Family and Community Medicine, 5323 Harry Hines Blvd, K2 Suite 400, Dallas, TX (E-mail: tgvoya@gmail.com). incoming students and faculty are intertwined, which requires an integrated approach for improving both student and faculty diversity. ${ }^{9-11}$ While the diversity of US medical students by sex and race/ethnicity has improved over the years, similar changes have been much more gradual for faculty. ${ }^{4,11}$ Despite this, department chairs are usually viewed as leaders who set the tone for diversity and inclusiveness of the faculty and training programs. ${ }^{12-14}$

To date, there has been no known report about diversity of department chairs in family medicine (FM). Data on diversity among department chairs have been lacking until reported recently by the Association of American Medical Colleges (AAMC) ${ }^{15}$ The purpose of this cross-sectional, observational study was to report the proportions of current or recent FM chairs at the Liaison Committee on Medical Education (LCME)accredited US medical schools according to sex and race/ethnicity. These proportions are compared with other clinical departments, FM faculty, 
medical school matriculants, and the US general population. Our hypothesis is that the diversity of FM chairs is similar to their faculty and medical students, greater than other faculty chairs and faculty combined, but less than the US population.

\section{Methods}

We used data from the AAMC Faculty Roster, a comprehensive national database of full-time faculty at all LCME-accredited US medical schools. Diversity data were obtained through the Faculty Administrative Management Online User System, a web-based tool for collecting comprehensive information on the characteristics of full-time faculty members at each LCME-accredited US medical school. $^{15}$

We used a 3-year study period, since 2018 was the first year in which sex and race/ethnicity were available for chairs at individual departments, and 2020 was the most recent year of available data. Data included the number of either permanent or interim chairs on December 31 of each year. Any FM department chair with missing sex data was excluded from analysis (only 1 chair each year). Accessible data were national and could not be subdivided into US regions (eg, South, Northeast, Midwest, West).

Racial and ethnic groups were defined mutually exclusive as Hispanic or Latino (of any race), nonHispanic White, non-Hispanic Black or African American, non-Hispanic Asian or Asian American, non-Hispanic Native American (American Indian, Alaska Native, Native Hawaiian, or Pacific Islander), and others (others, multiracial or unknown). Under-represented minority (URM) groups were described as under-represented relative to their numbers in the general population across the United States. ${ }^{16}$ Currently, they include Black, Hispanic (of any race), and Native American individuals. Although minorities, as a vast group, Asians are well represented as physicians in the United States.

We used the Duncan's multiple range test to measure specific differences between all pairs of proportions by sex, race, and ethnicity across FM department chairs, chairs in all other clinical departments, FM faculty (2020), other clinical department faculty (2020), matriculants at US medical schools (academic year 2019 to 2020), and US population (all 50 states, District of Columbia, and
Puerto Rico; 2019). ${ }^{15,17,18}$ We performed the 2-independent-sample $t$-test to compare the proportions and associated 95\% CIs for URM chairs across all major clinical departments. All $P$ values were 2 -sided, and a value $<0.05$ was deemed statistically significant. Statistical analyses were conducted with the SAS version 9.4 (SAS Institute, Cary, NC). No person was identified, and the University of Texas Southwestern Medical Center Institutional Review Board deemed this project to be exempt from human research guidelines.

\section{Results}

The total number of clinical department chairs increased minimally from 2398 in 2018 to 2404 in 2020. Interim or acting chairs constituted from $9.5 \%$ to $10.3 \%$ of all chairs, including those in FM. The 136 FM chair positions at the LCME-accredited US medical schools from 2018 to 2020 allowed for 407 person-year observations.

Table 1 lists sex and race/ethnicity for the FM chairs and 5 other population groups. The most common FM chair was a White male, yet this proportion was lower in FM than all other clinical departments combined $(57.2 \%$ vs $65.2 \% ; P \leq .01)$. The highest proportions of chairs who were female were within FM, obstetrics and gynecology, pediatrics, clinical pathology, and dermatology departments (range: $29.2 \%$ to $31.4 \%$ ).

As shown in Figure 1, the proportion of chairs who were URM was higher in FM compared with all clinical departments individually and combined (16.7\% vs $9.1, P \leq .001)$. The most common URM chair in FM was Black, regardless of sex. Representation of Blacks among FM chairs was more than among FM faculty and medical school matriculants and was comparable to the US general population (Table 1). We acknowledge the proportion of Hispanics as FM chairs was like that for all other department chairs combined and FM faculty but slightly below that for medical school matriculants and well below the US population (Table 1).

The proportions of Asians were comparable between FM chairs and the US general population (5.2\% vs $5.4 \%)$ but less than that for other department chairs, FM faculty, and medical school matriculants. The proportions of Native Americans were so small to note any differences between chairs, faculty, medical students, and the general 
Table 1. Comparison of Sex and Race/Ethnicity Between Department Chairs, Medical School Matriculants, Family Medicine Faculty, and the US Population, 2018-2020

\begin{tabular}{|c|c|c|c|c|c|c|}
\hline \multirow[b]{2}{*}{$\begin{array}{l}\text { Sex and Race/ } \\
\text { Ethnicity }\end{array}$} & \multicolumn{6}{|c|}{ No. (\%) [Duncan Grouping] } \\
\hline & $\begin{array}{c}\text { Fam } \\
\text { Medicine } \\
\text { Chairs }\end{array}$ & $\begin{array}{l}\text { Other Clinical } \\
\text { Chairs }\end{array}$ & $\begin{array}{c}\text { Fam Medicine } \\
\text { Faculty }\end{array}$ & $\begin{array}{l}\text { Other Clinical } \\
\text { Dept. Faculty }\end{array}$ & $\begin{array}{l}\text { Medical School } \\
\text { Matriculants }\end{array}$ & US Population \\
\hline Male & $\begin{array}{c}288(70.8) \\
{[B]}\end{array}$ & $\begin{array}{c}5,649(82.8) \\
{[\mathrm{A}]}\end{array}$ & $\begin{array}{c}2,785(46.1) \\
{[\mathrm{D}]}\end{array}$ & $\begin{array}{c}91,200(56.6) \\
{[C]}\end{array}$ & $\begin{array}{c}10,402(47.6) \\
{[\mathrm{D}]}\end{array}$ & $\begin{array}{c}161,469,052(49.2) \\
{[\mathrm{D}]}\end{array}$ \\
\hline White & $\begin{array}{c}233(57.2) \\
{[\mathrm{B}]}\end{array}$ & $\begin{array}{c}4,446(65.2) \\
{[\mathrm{A}]}\end{array}$ & $\begin{array}{c}2,007(33.2) \\
{[\mathrm{D}]}\end{array}$ & $\begin{array}{c}59,254(36.8) \\
{[\mathrm{C}]}\end{array}$ & $\begin{array}{c}5,002(22.9) \\
{[\mathrm{F}]}\end{array}$ & $\begin{array}{c}97,203,924(29.6) \\
{[\mathrm{E}]}\end{array}$ \\
\hline Asian & $\begin{array}{c}12(2.9) \\
{[\mathrm{E}]}\end{array}$ & $\begin{array}{c}612(9.0) \\
{[\mathrm{C}]}\end{array}$ & $\begin{array}{c}327(5.4) \\
{[\mathrm{D}]}\end{array}$ & $\begin{array}{c}18,805(11.7) \\
{[\mathrm{A}]}\end{array}$ & $\begin{array}{c}2,206(10.1) \\
{[\mathrm{B}]}\end{array}$ & $\begin{array}{c}8,402,724(2.6) \\
{[\mathrm{E}]}\end{array}$ \\
\hline Black & $\begin{array}{c}22(5.4) \\
{[\mathrm{A}]}\end{array}$ & $\begin{array}{c}176(2.6) \\
{[\mathrm{B}]}\end{array}$ & $\begin{array}{c}109(1.8) \\
{[\mathrm{B}]}\end{array}$ & $\begin{array}{c}2,494(1.5) \\
{[B]}\end{array}$ & $\begin{array}{c}619(2.8) \\
{[\mathrm{B}]}\end{array}$ & $\begin{array}{c}19,097,087(5.8) \\
{[\mathrm{A}]}\end{array}$ \\
\hline Hispanic & $\begin{array}{c}16(3.9) \\
{[\mathrm{B}, \mathrm{C}]}\end{array}$ & $\begin{array}{r}285(4.2) \\
{[\mathrm{B}, \mathrm{C}]}\end{array}$ & $\begin{array}{c}184(3.0) \\
{[\mathrm{C}]}\end{array}$ & $\begin{array}{c}5,274(3.3) \\
{[\mathrm{B}, \mathrm{C}]}\end{array}$ & $\begin{array}{c}1,133(5.2) \\
{[\mathrm{B}]}\end{array}$ & $\begin{array}{c}31,093,219(9.5) \\
{[\mathrm{A}]}\end{array}$ \\
\hline $\begin{array}{l}\text { Native } \\
\text { American }\end{array}$ & $\begin{array}{c}2(0.5) \\
{[\mathrm{A}]}\end{array}$ & $\begin{array}{c}15(0.2) \\
{[\mathrm{A}]}\end{array}$ & $\begin{array}{c}12(0.2) \\
{[\mathrm{A}]}\end{array}$ & $\begin{array}{l}206(0.1) \\
{[\mathrm{A}]}\end{array}$ & $\begin{array}{c}29(0.1) \\
{[\mathrm{A}]}\end{array}$ & $\begin{array}{c}1,317,664(0.4) \\
{[\mathrm{A}]}\end{array}$ \\
\hline $\begin{array}{l}\text { Others/ } \\
\text { Unknown }\end{array}$ & $\begin{array}{c}3(0.7) \\
{[\mathrm{E}]}\end{array}$ & $\begin{array}{c}115(1.7) \\
{[\mathrm{D}]}\end{array}$ & $\begin{array}{c}146(2.4) \\
{[\mathrm{C}]}\end{array}$ & $\begin{array}{c}5,167(3.2) \\
{[\mathrm{B}]}\end{array}$ & $\begin{array}{c}1,413(6.5) \\
{[\mathrm{A}]}\end{array}$ & $\begin{array}{c}4,354,434(1.3) \\
{[\mathrm{D}, \mathrm{E}]}\end{array}$ \\
\hline Female & $\begin{array}{c}119(29.2) \\
{[\mathrm{C}]}\end{array}$ & $\begin{array}{c}1,170(17.2) \\
{[\mathrm{D}]}\end{array}$ & $\begin{array}{c}3,252(53.9) \\
{[\mathrm{A}]}\end{array}$ & $\begin{array}{c}69,914(43.4) \\
{[\mathrm{B}]}\end{array}$ & $\begin{array}{c}11,461(52.4) \\
{[\mathrm{A}]}\end{array}$ & $\begin{array}{c}166,547,191(50.8) \\
{[\mathrm{A}]}\end{array}$ \\
\hline White & $\begin{array}{c}76(18.7) \\
{[\mathrm{D}]}\end{array}$ & $\begin{array}{c}865(12.7) \\
{[\mathrm{E}]}\end{array}$ & $\begin{array}{c}2,008(33.3) \\
{[\mathrm{A}]}\end{array}$ & $\begin{array}{c}41,852(26.0) \\
{[\mathrm{C}]}\end{array}$ & $\begin{array}{c}5,179(23.7) \\
{[\mathrm{C}]}\end{array}$ & $\begin{array}{c}99,926,008(30.5) \\
{[B]}\end{array}$ \\
\hline Asian & $\begin{array}{c}9(2.2) \\
{[\mathrm{D}]}\end{array}$ & $\begin{array}{c}132(1.9) \\
{[\mathrm{D}]}\end{array}$ & $\begin{array}{c}437(7.2) \\
{[\mathrm{C}]}\end{array}$ & $\begin{array}{c}14,827(9.2) \\
{[B]}\end{array}$ & $\begin{array}{c}2,481(11.3) \\
{[\mathrm{A}]}\end{array}$ & $\begin{array}{c}9,312,237(2.8) \\
{[D]}\end{array}$ \\
\hline Black & $\begin{array}{c}25(6.1) \\
{[\mathrm{A}]}\end{array}$ & $\begin{array}{c}86(1.3) \\
{[C]}\end{array}$ & $\begin{array}{c}268(4.4) \\
{[B]}\end{array}$ & $\begin{array}{c}3,664(2.3) \\
{[C]}\end{array}$ & $\begin{array}{c}1,007(4.6) \\
{[\mathrm{B}]}\end{array}$ & $\begin{array}{c}20,879,140(6.4) \\
{[\mathrm{A}]}\end{array}$ \\
\hline Hispanic & $\begin{array}{c}3(0.7) \\
{[\mathrm{D}]}\end{array}$ & $\begin{array}{c}58(0.9) \\
{[\mathrm{D}]}\end{array}$ & $\begin{array}{r}251(4.2) \\
{[\mathrm{B}, \mathrm{C}]}\end{array}$ & $\begin{array}{c}4,190(2.6) \\
{[C]}\end{array}$ & $\begin{array}{c}1,126(5.2) \\
{[B]}\end{array}$ & $\begin{array}{c}30,662,306(9.3) \\
{[\mathrm{A}]}\end{array}$ \\
\hline $\begin{array}{l}\text { Native } \\
\text { American }\end{array}$ & $\begin{array}{c}0(0.0) \\
{[\mathrm{A}]}\end{array}$ & $\begin{array}{l}0(0) \\
{[\mathrm{A}]}\end{array}$ & $\begin{array}{c}19(0.3) \\
{[\mathrm{A}]}\end{array}$ & $\begin{array}{l}162(0.1) \\
{[\mathrm{A}]}\end{array}$ & $\begin{array}{c}28(0.1) \\
{[\mathrm{A}]}\end{array}$ & $\begin{array}{c}1,367,671(0.4) \\
{[\mathrm{A}]}\end{array}$ \\
\hline $\begin{array}{l}\text { Others/ } \\
\text { Unknown }\end{array}$ & $\begin{array}{c}6(1.5) \\
{[\mathrm{D}]}\end{array}$ & $\begin{array}{c}29(0.4) \\
{[\mathrm{E}]}\end{array}$ & $\begin{array}{c}269(4.5) \\
{[\mathrm{B}]}\end{array}$ & $\begin{array}{c}5,219(3.2) \\
{[C]}\end{array}$ & $\begin{array}{c}1,640(7.5) \\
{[\mathrm{A}]}\end{array}$ & $\begin{array}{c}4,399,829(1.3) \\
{[D]}\end{array}$ \\
\hline Overall & $\begin{array}{c}407(100) \\
{[\mathrm{A}]}\end{array}$ & $\begin{array}{c}6,819(100) \\
{[\mathrm{A}]}\end{array}$ & $\begin{array}{c}6,037(100) \\
{[\mathrm{A}]}\end{array}$ & $\begin{array}{c}161,114(100) \\
{[\mathrm{A}]}\end{array}$ & $\begin{array}{c}21,863(100) \\
{[\mathrm{A}]}\end{array}$ & $\begin{array}{c}328,016,243(100) \\
{[\mathrm{A}]}\end{array}$ \\
\hline White & $\begin{array}{c}309(75.9) \\
{[\mathrm{A}]}\end{array}$ & $\begin{array}{c}5,311(77.9) \\
{[\mathrm{A}]}\end{array}$ & $\begin{array}{c}4,015(66.5) \\
{[\mathrm{B}]}\end{array}$ & $\begin{array}{c}101,106(62.8) \\
{[C]}\end{array}$ & $\begin{array}{c}10,181(46.6) \\
{[\mathrm{D}]}\end{array}$ & $\begin{array}{c}197,129,932(60.1) \\
{[\mathrm{C}]}\end{array}$ \\
\hline Asian & $\begin{array}{l}21(5.2) \\
{[\mathrm{D}]}\end{array}$ & $\begin{array}{c}744(10.9) \\
{[\mathrm{C}]}\end{array}$ & $\begin{array}{c}764(12.7) \\
{[B]}\end{array}$ & $\begin{array}{c}33,632(20.9) \\
{[\mathrm{A}]}\end{array}$ & $\begin{array}{c}4,687(21.4) \\
{[\mathrm{A}]}\end{array}$ & $\begin{array}{c}17,714,961(5.4) \\
{[\mathrm{D}]}\end{array}$ \\
\hline Black & $\begin{array}{c}47(11.5) \\
{[\mathrm{A}]}\end{array}$ & $\begin{array}{c}262(3.8) \\
{[C]}\end{array}$ & $\begin{array}{c}377(6.2) \\
{[\mathrm{B}]}\end{array}$ & $\begin{array}{c}6,158(3.8) \\
{[C]}\end{array}$ & $\begin{array}{c}1,626(7.4) \\
{[\mathrm{B}]}\end{array}$ & $\begin{array}{c}39,976,227(12.2) \\
{[\mathrm{A}]}\end{array}$ \\
\hline Hispanic & $\begin{array}{c}19(4.7) \\
{[\mathrm{C}]}\end{array}$ & $\begin{array}{c}343(5.0) \\
{[\mathrm{C}]}\end{array}$ & $\begin{array}{c}435(7.2) \\
{[\mathrm{C}]}\end{array}$ & $\begin{array}{c}9,464(5.9) \\
{[C]}\end{array}$ & $\begin{array}{c}2,259(10.3) \\
{[\mathrm{B}]}\end{array}$ & $\begin{array}{c}61,755,525(18.8) \\
{[\mathrm{A}]}\end{array}$ \\
\hline $\begin{array}{l}\text { Native } \\
\text { American }\end{array}$ & $\begin{array}{c}2(0.5) \\
{[\mathrm{A}]}\end{array}$ & $\begin{array}{c}15(0.2) \\
{[\mathrm{A}]}\end{array}$ & $\begin{array}{c}31(0.5) \\
{[\mathrm{A}]}\end{array}$ & $\begin{array}{l}368(0.2) \\
{[\mathrm{A}]}\end{array}$ & $\begin{array}{c}57(0.3) \\
{[\mathrm{A}]}\end{array}$ & $\begin{array}{c}2,685,335(0.8) \\
{[\mathrm{A}]}\end{array}$ \\
\hline $\begin{array}{l}\text { Others/ } \\
\text { Unknown }\end{array}$ & $\begin{array}{c}9(2.2) \\
{[\mathrm{C}]}\end{array}$ & $\begin{array}{c}144(2.1) \\
{[\mathrm{C}]}\end{array}$ & $\begin{array}{c}415(6.9) \\
{[\mathrm{B}]}\end{array}$ & $\begin{array}{c}10,386(6.4) \\
{[B]}\end{array}$ & $\begin{array}{c}3,053(14.0) \\
{[\mathrm{A}]}\end{array}$ & $\begin{array}{c}8,754,263(2.7) \\
{[C]}\end{array}$ \\
\hline
\end{tabular}

Duncan's multiple-range test for mean comparison (row-wise): listed in brackets; letters are ordered, and the highest proportion is assigned the letter A; proportions with the same letter are not significantly different $(\alpha=0.05)$. 
Figure 1. Proportions of all clinical department chairs who are under-represented minorities (URM), 2018 to 2020. Note: Bars represent $95 \%$ confidence intervals (CIs) for proportions of URM chairs.

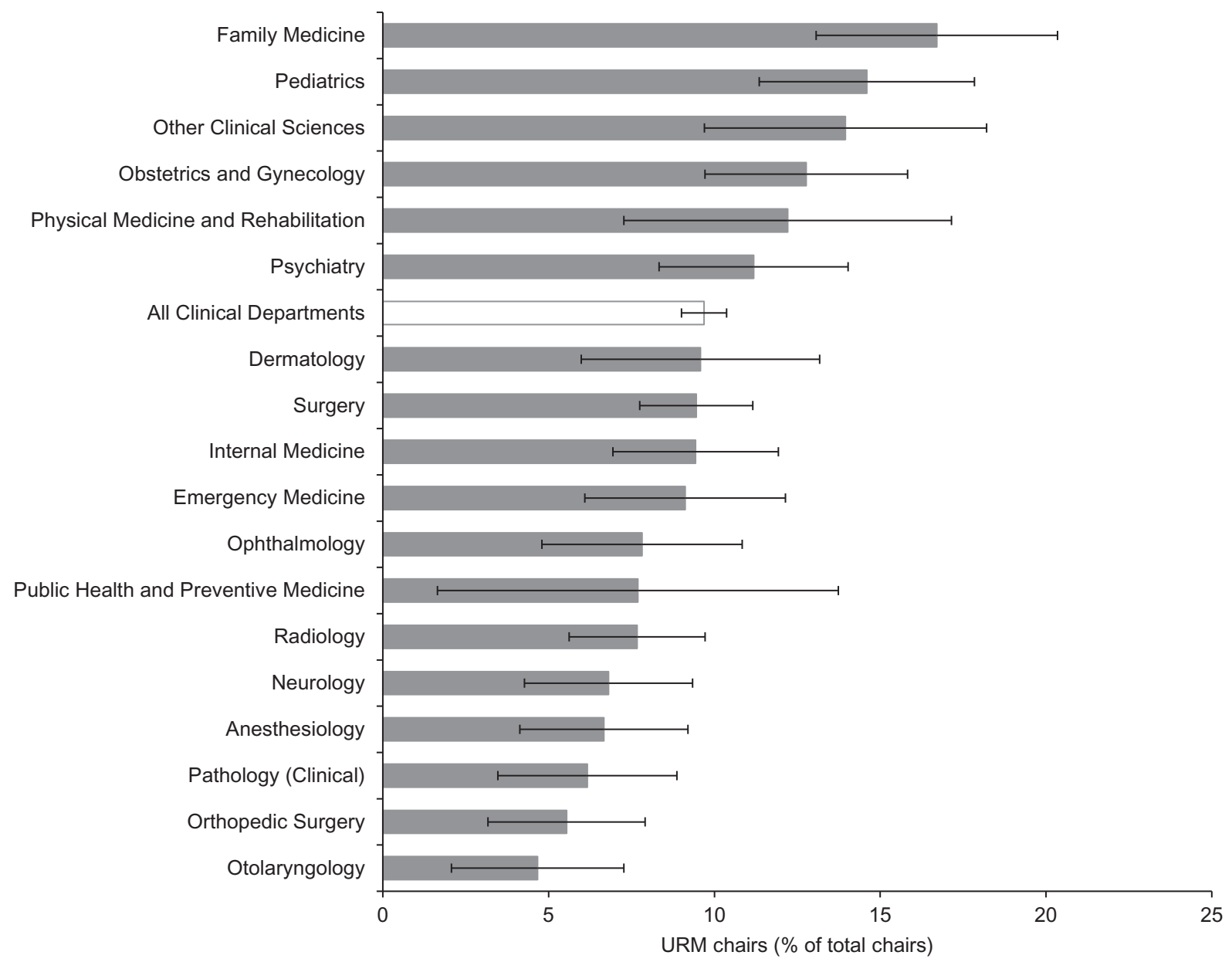

US population. All but 9 FM chairs (2.2\%) reported their racial/ethnic background.

\section{Discussion}

Racism, equity, diversity, and inclusion are pertinent issues to FM at all academic levels. Consideration of the combined sex and race/ethnicity among chairs of individual departments has not been published before, despite mounting interest in the subject. The roles of the FM department chair are many but include the promotion of diversity in improving the practice of primary care and community medicine.

Findings in our investigation reflect that FM chairs are among the most diverse of all clinical departments at US medical schools. Three key findings indicate that the traditional White male chair is less common in FM departments. Second, more females than males are faculty. With the reported increase in numbers and proportion of FM faculty who were female (from $21.5 \%$ in 1979 to $53.9 \%$ in 2020), we would assume that the number attaining senior rank and perhaps becoming chairs will increase. ${ }^{4}$ Thirdly, the proportion of FM chairs who are under-represented is the highest among clinical departments. The proportions of Black and Asian FM chairs are comparable to the US population. This greater diversity of sex and race/ethnicity among FM chairs is especially encouraging when realizing that family physicians care for the broadest segment of the US population. ${ }^{4,19,20}$

Our investigation was conducted over a 3-year period to better reflect department chairs rather than a single year. We combined characteristics of each chair (sex and race/ethnicity) to permit more details about diversity. The very small portion of 
chairs who did not self-report their race/ethnicity did not affect our conclusions.

A few limitations deserve mentioning. We could not differentiate as to whether this was the chair's first or second position and what was his/her age or tenure as chair. Data were available from AAMC for chairs of medical schools only and did not include community-based FM programs. Such a comparison would be a worthwhile future investigation. The proportion of all FM chairs who were interim was small, and we assumed that many became permanent chairs. ${ }^{21,22}$ Lastly, all our data were national, thereby not allowing us to examine any differences with FM chairs and faculty with their regional general populations.

Findings from this study can be applied to examining diversities of FM chairs and faculty as a reflection of their local and statewide population. The more rapid diversity of medical students should eventually lead to more recruitment of faculty and selection of chairs with different backgrounds. We were encouraged in a prior publication that FM faculty diversity was growing, and attention to URM representation should remain a priority. ${ }^{20}$ Hispanics accounted for more than half of total US population growth in the last decade, and recruitment of more Hispanic students is essential before we will see meaningful growth of Hispanic FM faculty and chairs. ${ }^{23,} 24$

A department chair position is time limited but critical for the advancement of our specialty and training the next generation of family physicians. Encouraging and cultivating diversity and inclusion should be a measurable commitment of current chairs to the future of their departments and physicians in training. We acknowledge that diversity issues can be considerably challenging. Regardless which career pathway female and URM faculty elect to choose, it is important that they receive support from their chair with appropriate mentors, assistance from their academic health center, and training at national leadership organizations. In this regard, intentional recruitment, retention, and development of a diverse faculty who may aspire to become a department chair are important workforce considerations for our profession and the patients we serve.

The authors have permission from the Association of American Medical Colleges to use Faculty Roster System data.

To see this article online, please go to: http://jabfm.org/content/ 35/1/152.full.

\section{References}

1. Henderson JT, Weisman CS. Physician gender effects on preventive screening and counseling: an analysis of male and female patients' health care experiences. Med Care 2001;39:1281-92.

2. Amalba A, Abantanga FA, Scherpbier AJ, van Mook WN. Community-based education: the influence of role modeling on career choice and practice location. Med Teach 2017;39:174-80.

3. Gonzalo JD, Chuang CH, Glod SA, McGillen B, Munyon R, Wolpaw DR. General internists as change agents: opportunities and barriers to leadership in health systems and medical education transformation. J Gen Intern Med 2020;35:1865-9.

4. Xierali IM, Nivet MA, Rayburn WF. Full-time faculty in clinical and basic science departments by sex and underrepresented in medicine status: a 40-year review. Acad Med 2021;96:568-75.

5. Nonnemaker L. Women physicians in academic medicine: new insights from cohort studies. $\mathrm{N} \mathrm{Engl}$ J Med 2000;342:399-405.

6. Umbach PD. The contribution of faculty of color to undergraduate education. Res High Educ 2006; $47: 317-45$.

7. Association of American Medical Colleges [Internet]. Striving toward excellence: faculty diversity in medical education; 2009 [cited 2021 July 9]. Available from: https://fdocuments.in/document/ striving-toward-excellence-facultydiversity-in-medical3-association-of.html.

8. Nivet MA. Commentary: diversity 3.0: a necessary systems upgrade. Acad Med 2011;86:1487-9.

9. Piercy F, Giddings V, Allen K, Dixon B, Meszaros $\mathrm{P}$, Joest K. Improving campus climate to support faculty diversity and retention: a pilot program for new faculty. Innov High Educ 2005;30:53-66.

10. Page KR, Castillo-Page L, Wright SM. Faculty diversity programs in U.S. medical schools and characteristics associated with higher faculty diversity. Acad Med 2011;86:1221-8.

11. Xierali IM, Fair MA, Nivet MA [Internet]. Faculty diversity in U.S. medical schools: progress and gaps co-exist. Association of American Medical Colleges Analysis in Brief; 2016 [cited 2021 July 11]. Available from: https://www.aamc.org/system/files/ reports/1/december2016facultydiversityinu.s.medical schoolsprogressandgaps.pdf.

12. Lindsey RW. The role of the department chair in prompting diversity. J Am Acad Orthop Surg 2007; 15:S65-S69.

13. Greene J, Lewis PA, Richmond GL, Stockard J. Changing the chairs: Impact of workshop activities in assisting chemistry department chairs in achieving racial and ethnic diversity. J Chem Educ 2011;88:721-5.

14. Evans A, Chun E. Department chairs as transformational diversity leaders. Department Chair 2015;25:1-3. 
15. Association of American Medical Colleges [Internet]. Faculty Roster: U.S. medical school faculty, 2018 through 2020; 2021 [cited 2021 May 10]. Available from: https://www.aamc.org/data-reports/facultyinstitutions/report/famous.

16. Association of American Medical Colleges [Internet]. Underrepresented in medicine definition; 2004 [cited 2021 July 11]. Available from: https://www.aamc.org/what-we-do/diversityinclusion/ underrepresented-in-medicine.

17. Association of American Medical Colleges Fact Tables [Internet]. Table A-9: matriculants to U.S. medical schools by race, selected combinations of race/ethnicity and sex, 2017-2018 through 2020-2021; 2021 [cited 2021 July 11]. Available from: https://www.aamc. org/media/6031/download.

18. United States Census Bureau [Internet]. The 2019 American community survey 5-year public use microdata sample (PUMS) files; 2020 [cited 2021 July 11]. Available from: https://data.census.gov/ mdat/\#/search?ds=ACSPUMS5Y2019.

19. Xierali IM, Hughes LS, Nivet MA, Bazemore AW. Family medicine residents: increasingly diverse, but lagging behind underrepresented minority population trends. Am Fam Physician 2014;90:80-1. Jul 15.
20. Xierali I, Nivet M, Gaglioti A, Liaw W, Bazemore A. Increasing family medicine faculty diversity still lags population trends. J Am Board Fam Med 2017;30:100-3.

21. Grigsby RK, Aber RC, Quillen DA. Commentary: interim leadership of academic departments at U.S. medical schools. Acad Med 2009;84: 1328-9.

22. Rayburn WF, Alexander H, Lang J, Scott JL. Firsttime department chairs at U.S. medical schools: a 29-year perspective on recruitment and retention. Acad Med 2009;84:1336-41.

23. Frey $\mathrm{WH}$ [Internet]. The nation is diversifying even faster than predicted, according to new census data. Washington, DC: Brookings; 2020 [cited 2021 July 11]. Available from: https://www.brookings.edu/research/ new-census-data-shows-the-nation-is-diversifying-evenfaster-than-predicted.

24. Krogstad JM [Internet]. Hispanics have accounted for more than half of total U.S. population growth since 2010. Washington, DC: Pew Research Center; 2020 [cited 2021 July 11]. Available from: https://www.pewresearch.org/fact-tank/2020/ 07/10/hispanics-have-accounted-for-more-thanhalf-of-total-u-s-population-growth-since-2010/ 